\title{
呼吸機能障害を有する肺癌手術症例に 対する呼吸理学療法の効果
}

張 性洙 ${ }^{* 1}$, 後藤 正司 ${ }^{* 1}$, 垂水晋太郎*1, 中島 尊*1, 亀山耕太郎*2

山本 恭通*1, 黄政龍*1, 横見瀬裕保*1

要旨

1999年 4 月から2003年12月までの期間に, 当科において肺切除を行った肺癌症例のうち周術期呼吸理学療法施行例 85例および非施行例142例を対象とし, 術後合併症の有無, 呼吸機能についてレトロスペクティブに検討した。術前呼 吸理学療法は, リラクセーション, 呼吸訓練, 咳の訓練, 下肢筋力トレーニング, 薬物療法を行い, 術後は, 術当日 よりベッドサイドで呼吸訓練, 排痰訓練・補助を開始し, 術翌日から基本動作訓練を行った。呼吸理学療法により FEV1.0及びVCは有意に改善した。FEV1.0及びVCは理学療法の施行期間に伴い改善した。 また呼吸器合併症は呼 吸理学療法施行群で有意に低かった。早期に周術期呼吸理学療法を開始することにより, 呼吸機能の改善と術後合併 症の減少が期待できる。

索引用語 : 呼吸理学療法, 肺癌, 肺切除, 術後合併症, 肺機能 respiratory physical therapy, lung cancer, lung resection, postoperative complication pulmonary function

\section{目的}

呼吸器機能障害を有する症例に対する肺癌手術の際 には, 術後合併症の増加や術後呼吸不全, 消極的縮小 手術に伴う根治度の低下などの問題がある。我々の施 設では, 肺癌にて肺切除を予定している患者に対し術 前術後に呼吸理学療法を行っており, その周術期にお ける呼吸理学療法の効果について検討した。

\section{対象と方法}

1999年 4 月から2003年12月までの期間に，当科にお いて肺切除を行った周術期呼吸理学療法施行例85例お よび非施行例142例の計227例を対象とした。呼吸機能 検査を入院時全例に施行し, 呼吸理学療法群では術前 に再度呼吸機能検査を施行した。術後合併症の有無,

*1香川大学医学部 呼吸器 $\cdot$ 乳腺内分泌外科

*2倉敷中央病院 呼吸器外科

原稿受付 2007年 6 月19日

原稿採択２007年 8 月22日
呼吸機能の改善率，喫煙歴等をレトロスペクティブに 検討した．統計学的検討は $\mathrm{t}$ 検定を用いて行い， P 值 が0.05未満を有意差ありと判定した。

術前呼吸理学療法は, 術後理学療法の目的と具体的 な方法を理解, 習得させることと, 術前に可能な限り 呼吸機能と運動能を向上させることを目的とし，リラ クセーション, 呼吸訓練, 咳の訓練, 下肢筋力トレー ニングを行った。閉塞性障害の強い症例には薬物療法 として $\beta$ 刺激剤および抗コリン剂の吸入を行った。

術後呼吸理学療法は, 術当日よりベッドサイドで呼 吸訓練, 排痰訓練・補助を開始し, 術翌日から基本動 作訓練を開始した。

リラクセーション：リラックスした状態で呼吸する 感覚の学習や, 全身の筋肉の弛緩とともに呼吸補助筋 の活動を抑制し基礎代謝量の低減を目的として施行.

1 日 1 回, 術前・術後共に施行した。

呼吸訓練：横隔膜呼吸訓練，ボルダイン ${ }^{\circledR}$ (Kendall Sherwood-Davis \& Greck, USA）（Fig. 1a）を使用し た吸気筋トレーニング，スーフル ${ }^{\circledR}$ (Kayaku Co.， 


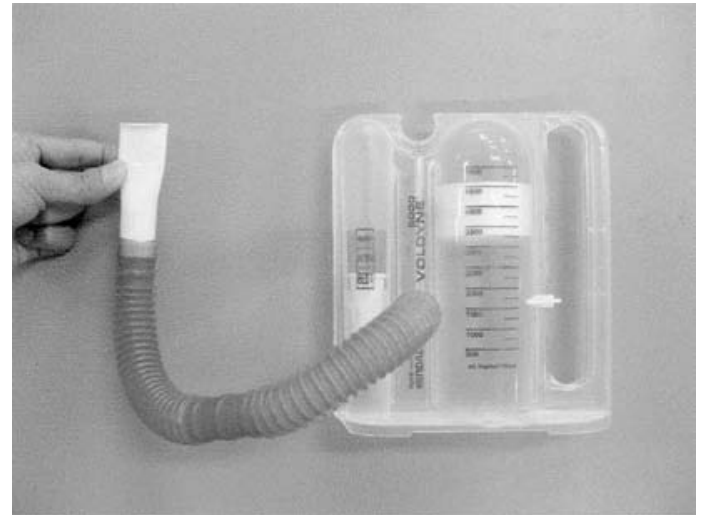

(a)

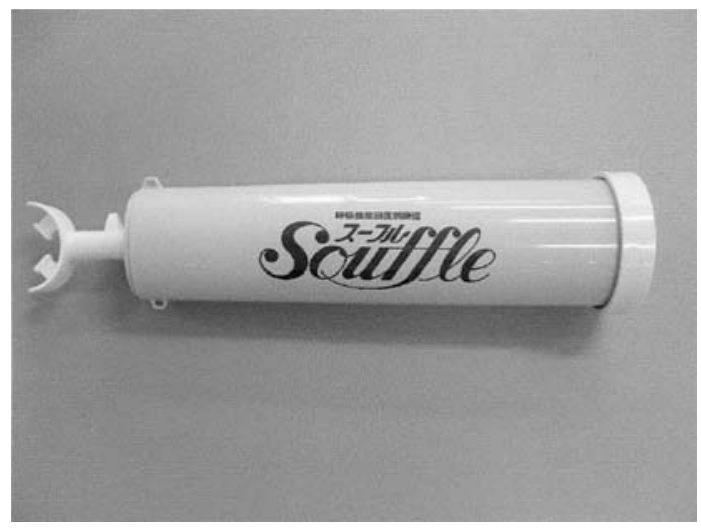

(b)

Fig. 1a Voldyne 5000 Incentive Spirometers Exerciser ${ }^{\circledR}$ is the breath trainer for the improvement of the maximum inspiration volume and time.

Fig. 1b Souffle ${ }^{\circledR}$ gives a resistance during the phase of expiration. As the expiration pressure exceeds the resistance, Souffle ${ }^{\circledR}$ produce the deep sound.

Ltd., Tokyo, Japan）(Fig. 1b）を用いた呼気筋トレー ニング, 呼出力の改善を目的に横隔膜呼吸と同期させ た下肢挙上訓練や頭部挙上などの体幹筋（腹筋群）卜 レーニングを施行。主に術前に1日1回施行した。

咳嗽訓練：効果的な咳の練習とともに，高齢者や効 果的な咳が困難な場合はハッフィング (huffing : 最大 吸気後に呼気を長く呼出させる排痰法のひとつ）の指 導を施行. 術前後に 1 日 1 回施行した.

下肢筋カトレーニング : 下肢の筋力と有酸素能力の 向上を目的として自転車エルゴメーターを用いた卜 レーニングを施行した。 心拍数を指標とした有酸素運 動の範囲で30分程度の運動を 1 日 1 回施行した.

基本動作訓練：起立，歩行といった早期離床に関す る基本動作訓練を術翌日から施行した。

\begin{tabular}{cccc} 
& $\begin{array}{c}\text { Total } \\
\mathrm{n}=207\end{array}$ & $\begin{array}{c}\text { PT } \\
\mathrm{n}=85\end{array}$ & $\begin{array}{c}\text { Non PT } \\
\mathrm{n}=142\end{array}$ \\
\hline $\begin{array}{c}\text { Age } \\
\text { Male/Female }\end{array}$ & $\begin{array}{c}6.3 \pm 11.1 \\
163 / 64\end{array}$ & $66.7 \pm 10.2$ & $65.2 \pm 11.8$ \\
\hline p-stage I & 137 & 45 & $99 / 43$ \\
II & 28 & 17 & 17 \\
III & 52 & 21 & 31 \\
IV & 4 & 2 & 2 \\
\hline VC (L) & $2.77 \pm 0.84$ & $2.64 \pm 0.81$ & $2.86 \pm 0.86$ \\
FEV1.0 (L) & $2.03 \pm 0.73$ & $1.84 \pm 0.73$ & $2.19 \pm 0.70$ \\
\hline Pneumonectomy & 24 & 12 & 12 \\
Lobectomy & 158 & 52 & 106 \\
Segmentectomy & 10 & 6 & 4 \\
Partial & 35 & 15 & 20 \\
\hline
\end{tabular}

Fig. 2 Clinical background of patients.

これらは基本的には術前であれば外来で施行可能で ある。

\section{結 果}

呼吸理学療法群の平均年齢は $66.7 \pm 10.2$ 歳, 入院時 の VCは $2.64 \pm 0.81 l, F E V 1.0 は 1.84 \pm 0.73 l$, 非施行 群の平均年齢は $65.2 \pm 11.8$ 歳, 入院時の VC は2.86 $0.86 l$, FEV1.0は2.19 $0.70 l$ で, 各臨床背景に有意な 差は認めなかった（Fig. 2).

術後肺炎および無気肺の呼吸器合併症は呼吸理学療 法群で 5 例 $(5.9 \%)$ ，非施行群で20例（14.1\%）を認 め, 理学療法群が有意 $(\mathrm{p}=0.040)$ に低かった（Fig. 3) 入院時の FEV1.0およびVCによる術後呼吸器合併症 の発生率には有意差を認めなかったが, 低肺機能群で の発生率が高い傾向にあった。また，呼吸器合併症発 生例においては有意にブリンクマン指数が高值であっ た $(p=0.0072)$ ．その他の合併症の発生および死亡率 には有意差を認めなかった。

呼吸理学療法群の理学療法後の FEV1.0は1.97士 $0.68 l, V C$ は $2.76 \pm 0.81 l$ であった。入院時と比較する と FEV1 改善率は $10.0 \pm 17.7 \%, V C$ 改善率は $3.9 \pm$ 10.5\%で，それぞれ施行前と比較し有意な（FEV1：p $<0.00001, \mathrm{VC}: \mathrm{p}=0.00003)$ 改善が認められた.

呼吸理学療法群 85 例のうち, 入院時の呼吸機能検査 で閉塞性障害が認められた27例の FEV1.0改善率は 20.0\%，閉塞性障害が認められなかった58例の FEV1

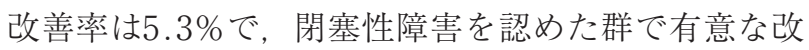


善が認められた。また，入院時に拘束性障害が認めら れた41例の VC 改善率は $4.0 \%$, 拘束性障害が認められ なかった44例の VC 改善率は $3.9 \%$ で, 有意な差は認め られなかった (Fig. 4)。また薬剤投与の有無による比 較では有意差を認めなかった。

理学療法施行期間別にみると, FEV1.0の改善率は, 施行期間 1 週未満では1.7\%，1～ 2 週では8.7\%, 2 週以上では $19.2 \% て ゙, V C$ の改善率は呼吸理学療法施 行期間 1 週未満では0.1\%, 1〜2 週では $3.5 \%, 2$ 週 以上では $8.1 \%$ あったた FEV1, VC とも施行期間の 長さに伴い改善が認められた（Fig. 5).

\begin{tabular}{lccc} 
& $\begin{array}{c}\text { Total } \\
\mathrm{n}=227\end{array}$ & $\begin{array}{c}\mathrm{PT} \\
\mathrm{n}=85\end{array}$ & $\begin{array}{c}\text { Non PT } \\
\mathrm{n}=142\end{array}$ \\
\hline $\begin{array}{l}\text { Pneumonia/ } \\
\text { atelectasis }\end{array}$ & $25(11.0 \%)$ & $5(5.9 \%)$ & $20(14.1 \%)$ \\
$\begin{array}{l}\text { Respiratory } \\
\text { failure }\end{array}$ & $3(1.3 \%)$ & $1(1.2 \%)$ & $2(1.4 \%)$ \\
$\begin{array}{l}\text { Arrythmia/ } \\
\text { heart failure }\end{array}$ & $9(4.0 \%)$ & $5(5.9 \%)$ & $4(2.8 \%)$ \\
$\begin{array}{l}\text { Other } \\
\text { Mortality }\end{array}$ & $6(2.6 \%)$ & $2(2.4 \%)$ & $4(2.8 \%)$ \\
\hline
\end{tabular}

Fig. 3 Postoperative complications.

There was a significant difference between the PT and non-PT groups in the occurrence of respiratory complications $(\mathrm{p}=0.040)$ (PT: Physical therapy).

\section{考察}

肺切除後の術後呼吸器合併症の発生頻度は17～39\% と高く ${ }^{1-3)}$, 呼吸器合併症の発生は術関連死亡の最も 大きな原因の一つとなっている4,5).今回の検討では, 理学療法群の術後呼吸器合併症の発生は有意に低く, 周術期の呼吸理学療法は術後合併症の予防に有用と思 われた。

術前低肺機能は，術後合併症の発生や死亡率を増大 する要因として挙げられている 予測 FEV1.0は手術適応の一つの指標とされ，根治手 術施行後の予測％FEV1.0が40\%未満の症例では消極 的縮小手術への術式の変更や，手術以外の治療法の検 討がしばしば必要となる9 ${ }^{9)}$. 今回, FEV1.00改善が理 学療法群に, 特に閉塞性障害を有する群で著明に認め られたことは，呼吸理学療法により術後合併症の減少 が図れるだけでなく, 症例によっては消極的縮小手術 から根治手術への術式の変更も可能となることを示し ている.

一方, 呼吸理学療法により VCも一定の改善が認め られたが，拘束性障害の認められた群ではVCに改善 が認められなかった。拘束性障害の多くはVCの低下 が肺の器質自体に起因しており，呼吸理学療法による VCの改善が期待しにくいものと思われた。

理学療法施行期間についての検討では, FEV1.0,
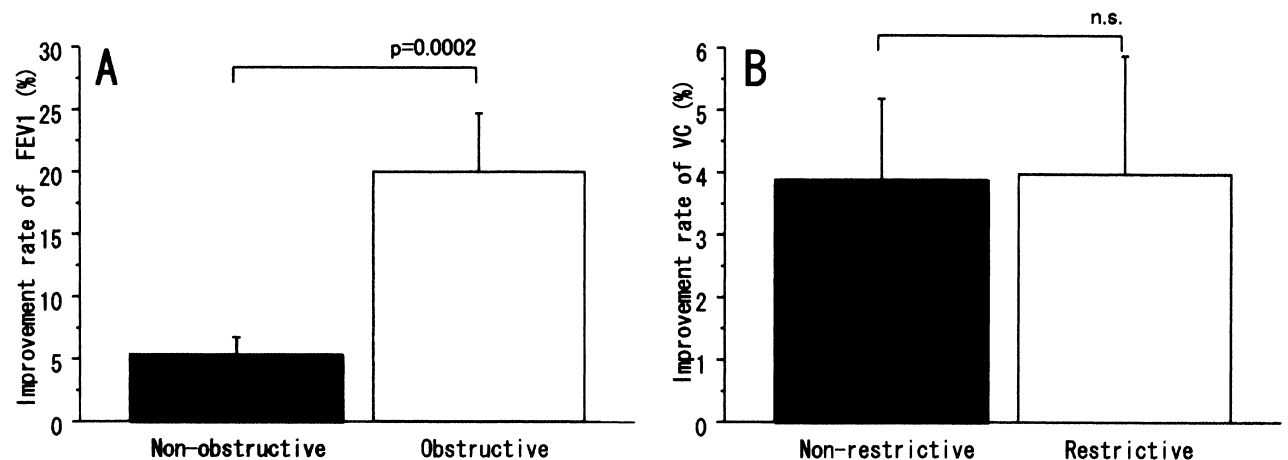

Fig. 4 Improvement rate of respiratory function by PT in groups with obstructive and restrictive disease.

A: The improvement rate of FEV1.0 was $20.0 \pm 24.0 \%$ in the group with (27 patients, FEV1.0\%<70\%) and $5.3 \pm 11.3 \%$ in the group without (58 patients, FEV1.0\% $\geq 70 \%)$ obstructive disease; the group with obstructive disease showed a significantly better improvement $(\mathrm{p}=0.0002)$. B: The improvement rate of VC was $4.0 \pm 12.2 \%$ in the group with ( 41 patients, $\% \mathrm{VC}<80 \%)$ and $3.9 \pm 8.7 \%$ in the group without $(44, \% \mathrm{VC} \geq 80 \%)$ restrictive disease; there were no significant difference in the improvement rate. 

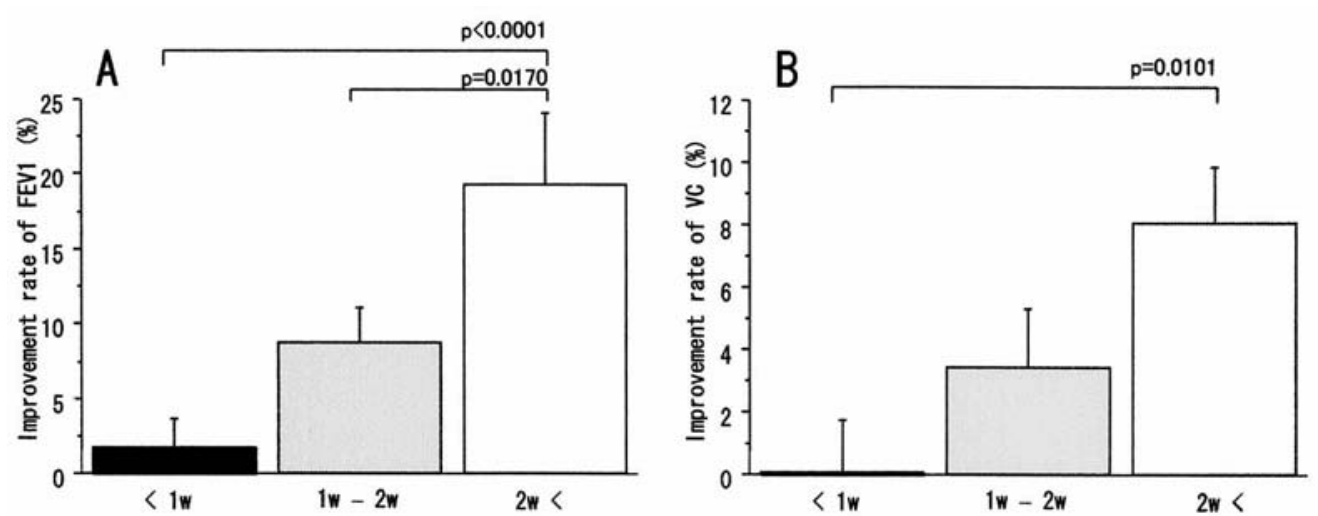

Fig. 5 Improvement rate of respiratory function by the duration of PT.

A: The improvement rates of FEV1 by the duration of PT were $1.70 \pm 8.76 \%$ in 1 week or less, $8.75 \pm 14.3 \%$ in 1 to 2 weeks, and $19.2 \pm 23.9 \%$ in 2 weeks or more. Significant differences were found among the 2 groups ( 1 week or less vs. 2 weeks or more, $\mathrm{p}<0.0001$; 1 to 2 weeks vs. 2 weeks or more, $\mathrm{p}=0.0170)$. B: The improvement rates of VC by the duration of PT were $0.08 \pm 7.8 \%$ in 1 week or less, $3.5 \pm 11.8 \%$ in 1 to 2 weeks, and $8.1 \pm 8.9 \%$ in 2 weeks or more. Significant differences were found between the rates for 1 week or less and 2 weeks or more $(p=0.0101)$.

VC ともに施行期間に伴い改善が認められた。肺癌の 場合は術前にあまり猶予期間がないが，特に閉塞性障 害を有する場合は, 呼吸機能の改善により消極的縮小 術を回避できる可能性がある10)。また, 呼吸器合併症 のリスクが高いと考えられる低肺機能群では特に理学 療法の効果が期待できるということが示唆された、今 後, 当院での肺切除症例では全例に術前理学療法を施 行する予定であるが, 特に低肺機能症例や喫煙者では 十分な時間をかけて呼吸理学療法を行なうことが重要 と思われた。

\section{まと め}

呼吸理学療法を施行した症例の術後呼吸器合併症の 頻度は, 非施行群より低かった。呼吸理学療法により FEV1.0およびVCは改善し, その施行期間に伴い改善 が認められた。早期に呼吸理学療法を施行することに より, 呼吸機能の改善と術後合併症の減少が期待でき る.

\section{文献}

1. Kearney DJ, Lee TH, Sugarbaker DJ, et al. Assessment of operative risk in patients undergoing lung resection. Importance of predicted pulmonary function. Chest 1994; 105: 753-9.

2. Busch E, Verazin G, Antkowiak JG, Driscoll D, Takita H. Pulmonary complications in patients undergoing thoracotomy for lung carcinoma. Chest 1994; 105: 760-6.

3. Stephan F, Boucheseiche S, Hollande J, Flahault A, Cheffi A, Bazelly B, et al. Pulmonary complications following lung resection: a comprehensive analysis of incidence and possible risk factors. Chest 2000; 118: 1263-70.

4. Ginsberg RJ, Hill LD, Eagan RT, Thomas P, Mountain $\mathrm{CF}$, Deslauriers J, et al. Modern thirty-day operative mortality for surgical resections in lung cancer. J Thorac Cardiovasc Surg 1983; 86: 654-8.

5. Wada H, Nakamura T, Nakamoto K, Maeda M, Watanabe Y. Thirty-day operative mortality for thoracotomy in lung cancer. J Thorac Cardiovasc Surg 1998; 115: 70-3.

6. Gass GD, Olsen GN. Preoperative pulmonary function testing to predict postoperative morbidity and mortality. Chest 1986; 89: 127-35.

7. Datta D, Lahiri B. Preoperative evaluation of patients undergoing lung resection surgery. Chest 2003; 123: 2096-103.

8. Pierce RJ, Copland JM, Sharpe K, Barter CE. Preoperative risk evaluation for lung cancer resection: predicted postoperative product as a predictor of surgical mortality. Am J Respir Crit Care Med 1994; 150: 947-55.

9. Beckles MA, Spiro SG, Colice GL, Rudd RM. The physiologic evaluation of patients with lung cancer being considered for resectional surgery. Chest 2003; 123: 10514.

10. Semik M, Schmid C, Trosch F, Broermann P, Scheld HH. Lung cancer surgery-preoperative risk assessment and patient selection. Lung Cancer 2001; 33: 9-15. 


\title{
The efficacy of perioperative pulmonary physical therapy for patients with respiratory compromise
}

\author{
Sung Soo Chang*1, Masashi Gotoh*1, Shintaro Tarumi*1, Takashi Nakashima*1, Koutaro Kameyama*2 \\ Yasumichi Yamamoto*1, Cheglong Huang*1, Hiroyasu Yokomise*1 \\ ${ }^{* 1}$ Department of General Thoracic, Breast, and Endocrinological Surgery, Faculty of Medicine, Kagawa University \\ *2Department of General Thoracic Surgery, Kurashiki Central Hospital
}

The clinical efficacy of perioperative physical therapy (PT) for patients undergoing pulmonary resection for lung cancer was investigated. The subjects were 227 patients who underwent pulmonary resection for lung cancer; PT was performed in 85 of them. The content of PT consisted of breathing exercises, systemic training, and coughing exercises. Postoperative respiratory complications were significantly decreased in the PT group. FEV1 and VC were significantly improved by PT. Especially, marked improvement was found in patients with obstructive disease. The improvement of respiratory function was correlated with the duration of PT. Initiating perioperative PT was beneficial for patients undergoing lung resection, in terms of reducing the occurrence of postoperative complications and improving respiratory function. 